\title{
Die teologiese ensiklopedie volgens Rudolf Bultmann
}

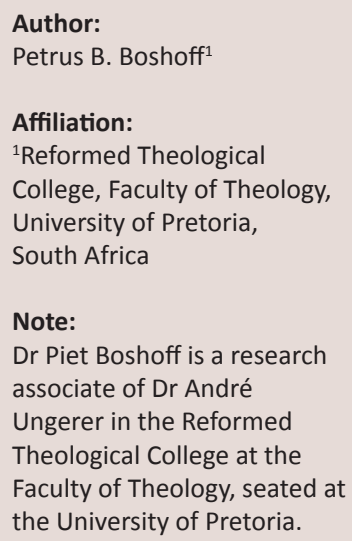

\section{Copyright:}

C 2015. The Authors. Licensee: AOSIS

OpenJournals. This work is licensed under the Creative Commons Attribution License.

\section{Read online:}

The theological encyclopedia according to Rudolf Bultmann. The purpose of this article is to present Bultmann's view on theology. The theme is relevant, since there is confusion as to what theology is or should be. Although his theological contribution remains under attack, Bultmann often complained of being misunderstood. Therefore it is necessary to read his work carefully and to reconsider his approach. The author started with themes Bultmann discussed in his lectures on theological encyclopaedia, published posthumously, and elaborates on them with reference to his other published work.

\section{Inleiding}

Die Duitse teoloog, Gerhard Ebeling (1978:10-11) voer aan dat die teologiese situasie heeltemal ondeursigtig geword het. Verskeie mense wat met teologiebeoefening besig is, voel dit ook aan. Die feit dat spesialisering, kompetisie en joernalistiek bydra tot 'n oormatige produksie van teologiese leesstof sorg ook nie vir opheldering nie; inteendeel, die probleem word daardeur eerder vererger. Hierdie waarneming geld ook nie net vir die Duitse teologie nie, dit kan maar van die hele teologiese spektrum gesê word.

Wanneer die beoefenaars van 'n wetenskap hulle telkens weer afvra waaroor dit nou eintlik gaan, moet dit glad nie as ' $n$ teken van swakheid beskou word nie. Dit is maar iets wat gereeld gedoen moet word. Teoloë hoef dus glad nie daarvoor terug te deins nie, maar moet liewer die geleentheid aangryp. Miskien sal dit selfs 'n aanduiding van dwaling en seniliteit wees wanneer die problematiek geïgnoreer word.

Om 'n bietjie rigting te midde van hierdie onsekerheid te kry, moet daar sekerlik ernstig besin word oor 'n ensiklopediese oorsig van die teologie. So sal studente kan agterkom wat hulle moet bestudeer en sal dosente hulleself kan meet aan die opdrag wat hulle ontvang het. Hierdie noodsaaklike besinning kan net daarby baat deur kennis te neem van hoe Rudolf Bultmann oor die saak gedink en gedoseer het. Hy het die probleme energiek deurdink en op selfstandige wyse in 'n rigting beweeg. Ook vir dié wat nie heelpad met hom saamloop nie, kan dit net leersaam wees om van Bultmann se standpunt kennis te neem.

Wat is die voorwerp wat die teologie ondersoek? Die ondersoek gaan nie oor die Christendom as historiese verskynsel nie, maar oor die hart van die Christendom, dit wat die Christendom tot Christendom maak, dit wat legitiem as Christelik geld en die Christendom en die teologie konstitueer: die Christelikheid, ons 'ontwyfelbare Christelike geloof' en dit wat deur die geloof omhels word. Teologie wat wil verduidelik wat die inhoud en betekenis van die geloof is, kan aan die gerigtheid daarvan op God nie verbygaan nie. Wat is dit wat teologie as teologie konstitueer en hoe bepaal dit die wetenskapskarakter van die teologie? Dit is wat die ensiklopedie van die teologie as selfbesinning moet aantoon (Bultmann 1984:12).

Bultmann (1984:2) beperk die begrip 'ensiklopedie' deur dit teologiese ensiklopedie te noem en die fokus te laat val op sake soos die voorwerp van ondersoek wat hier onthul word; die eise wat aan hierdie ondersoek gestel word; die fondament waarop in hierdie wetenskap gebou word; en die begripsmateriaal wat hier gepas sal wees.

Die bepaling teologiese by ensiklopedie beklemtoon dat dit gaan om 'n spesifieke wetenskap in onderskeid tot ' $n$ algemene ensiklopedie wat as wetenskapsleer gerig is op wetenskap as sodanig: Wat is wetenskap? Waaroor gaan dit in die wetenskap?

Die 'wetenskapsleer' van die Idealisme beskryf 'n sisteem van wetenskap waarin alle saakgebiede, alles wat bestaan, teruggaan na een oorsprong en as eenheid te begryp is en dat dié oorsprong tegelyk die oorsprong van die wetenskap is. Die oorsprong waaruit alle syndes en die denke 
spruit, is die absolute wat as logos - gees - voorgestel word. Deur sy verligte verstand kry die mens deel aan die oorspronklike redelikheid wat alles beheers. Die redelike wetenskapsisteem geniet voorrang bo die syndes, sodat nie die voorwerpe van ondersoek nie, maar die idee van die gees die wetenskappe konstitueer. Wat teologie is, word dan nie bepaal deur die voorwerp van ondersoek, God, nie, maar afgelei uit die redelike oorsprong van alle dinge. Die Idealistiese filosofie gaan die teologie vooraf en teologie word godsdiensfilosofie, wat inhou dat die Christendom aan die hand van wat hoegenaamd as godsdiens beskou word, beoordeel word. So 'n beoordeling geskied dan van buite af, vanuit gesigspunte wat nie tot die eie karakter van die Christelike behoort nie, maar willekeurig vanuit 'n vantevore opgemaakte skema.

Die ontwikkeling van die eksakte wetenskappe het die idee van die gees as die oorsprong verdring. Die Positivisme het ontstaan, wat leer dat die wêreld van die syndes die werklikheid uitmaak. Matematiese beheerbaarheid sorg vir die eenheid van alles wat gemeet en bereken kan word. Daar is een wetenskap met een ondersoekgebied - die wêreld as natuur. Ook die mens word as natuurverskynsel gesien en volgens die natuurwetenskaplike metodes ondersoek deur psigologie, sosiologie en biologie.

Teologie word gereduseer tot die ondersoek van die mens in soverre hy vanuit sy godsdienstige behoeftes voorstellings van God maak, en dit word ingedeel by Godsdienswetenskap, wat godsdiens as psigologiese of sosiologiese verskynsel beskryf. Vir Christelike teologie as wetenskap van God, as teenoor die mens staande, is daar nie ruimte nie (Bultmann 1984:4). Wat teologie moes wees, word vervang deur godsdienspsigologie en godsdienssosiologie.

\section{Wetenskap en waarheid}

Bultmann ([1933] 1968:294-295; 1984:35) haal Nietzsche instemmend aan wat oor ons moderne mense kla dat ons 'wandelende ensiklopedieë' geword het, met die gevolg dat ons gewoond daaraan geraak het om niks meer ernstig op te neem nie. Kennis is nie die onthulling van 'n bepaalde voorwerp nie, maar 'n funksie van die rede wat in homself opgesluit is. Die gevleuelde uitdrukking van Wagner: 'Ek weet nou wel baie, maar ek sal graag alles wil weet' gee duidelik uiting aan die misverstand as sou die menslike eksistensie afgeslote kon wees, en dat daarmee saam, die kennis ook afgeslote sou kon wees (Bultmann 1984:38-39).

Egte kennis is kennis wat deur die gekende voorwerp bepaal word en waarheid kom neer op die ontsluiting van die voorwerp (Bultmann 1984:42). Die ontsluiting gebeur net waar die voorwerp en die eksistensie in 'n lewendige verhouding optree. Waarheid en die objektiwiteit van ons kennis word bepaal deur die ontsluiting van die voorwerp wat ons leer ken. Die eksaktheid van ons kennis word nie deur die matematiek bepaal nie, maar deur die saaklikheid daarvan. Waarheid het deurgaans die betekenis van die aanspraak: 'Anspruch des Gegenstandes auf uns' (Bultmann
1984:43). Die kriterium vir wetenskaplikheid word bepaal deur die inlewing van die ondersoeker in die voorwerp van ondersoek en dan die opheldering daarvan. Selfs iemand wat die geloof as 'n opium beskou, sou nie kan ontken dat die Christelike geloof 'n ondersoek werd is nie.

Die waarheid is algemeen geldig. Elkeen wat die bepaalde voorwerp sien soos dit werklik is, moet dit sien soos ek dit sien en soos ek daarvan verslag doen. 'n Saak kan vanuit verskillende hoeke benader word, maar wanneer dit dieselfde saak is waaroor dit gaan, moet dit die verskillende hoeke van dieselfde saak wees, want die voorwerp van ondersoek bepaal die uitkoms van die ondersoek (Bultmann 1984:46; 186-187). Die teologie bly ingestel op wat eg-Christelik is en skuif die variante van besonder-Christelike aansprake eenkant toe. Vir konfessionalistiese selfgenoegsaamheid kan daar nie simpatie wees nie. Teologie is dus ook iets heel anders as 'n subjektiewe belydenis.

Die waarheid van die geloof is net so algemeen geldig soos dié van die wetenskap. Onder 'subjektiwiteit' van die geloof word net bedoel dat die voorwerp van geloof nie so 'algemeen' toeganklik is op die manier waarop wêreldlike dinge te voorskyn tree nie (Bultmann 1984:47).

Daar is soveel waarhede soos wat daar voorwerpe is wat vir ontsluiting toeganklik is. Die eksistensie vra egter nie na waarhede nie, maar na die waarheid om homself te verstaan, wat insluit dat hy sal weet wat om te doen. Wie is ek nou eintlik? Waar hoort ek? Die logiese benadering van die mens is egter om soveel as moontlik te wil weet, sodat hy nie miskien iets van belang sou oorslaan nie en om langs dié weg by die geheelbeeld, die sisteem wat dan die waarheid moet wees, uit te kom. Hy tree op deur vaardighede uit te voer om 'iets tot stand te bring'; nie om homself te vind nie. Die veronderstelling waarvan hy uitgaan, is dat hy reeds by homself uitgekom het. Hierdie benadering sluit dan die vraag na waarheid uit omdat die mens nie na sy ware self vra nie. Hy het die kennis net nodig om iets te doen; nie om homself te verstaan nie (Bultmann 1984:47-48).

Die oorspronklike vraag na waarheid word egter gevra met die veronderstelling dat dit om my gaan, dat ek deur my optrede tot my reg kom. Die hele waarheid, my waarheid, is op die spel. Volgens die Idealisme is die waarheid, die ken van jouself, dat jy sal weet dat dit die logos, die rede, die gees in jou is wat aan die wêreld en aan jou eenheid en werklikheid verleen. Volgens hierdie beskouing is die menslike rede skeppend van aard en identies met die 'absolute', die 'goddelike' rede, waarvan die vorms en wette van die werklikheid afhanklik is. Die logos, rede praat in alle verstande, maar kom tot homself in die filosofie wat die vraag na waarheid beantwoord. Die ek word verstaan as 'n verskynsel van die kosmos. Die ideaal waaraan 'n mens moet beantwoord, is om self kosmies, harmonieus te word deur bepaalde deugde soos wysheid, manlikheid, selfbeheersing deugde wat saamgevat word as geregtigheid. Die menslike bestaan word verstaan wanneer dit as deel van die ordenende sisteem gesien word. Die waarheid maak tegelyk ook sin, sin 
wat die tydlose eenheid van die sisteem vorm (Bultmann 1984:49-50; 184).

In die Idealisme word die tydelikheid, die geskiedmatigheid, 'Geschichtlichkeit' van die menslike bestaan uitgeskakel. Waar die geskiedmatigheid in ag geneem word, kan die inpas by die ewige, tydlose ordeninge nie die verstaan van die eksistensie bevredig nie, want in die tyd is elke oomblik nuut en het sy eie raaisel.

Bultmann (1984:185) wys daarop dat die moderne vraag na die waarheid van die geskiedenis ooreenstem met die Griekse vraag na waarheid. Daar word gesoek na die sin, die eenheid en orde van alles wat gebeur in die tyd. Wie dit kan aantoon, voel beskut. Maar die eenheid en orde van alles kan nog nie iemand se persoonlike, eksistensiële waarheid wees nie.

Waarheid kan gesien word as die erkenning van die wette wat die wêreld as natuur tot eenheid bind en wat die menslike samelewing tot 'n gemeenskap vorm. Maar volgens die Christelike standpunt het waarheid te doen met die werklikheid van God, en die erkenning van die waarheid word die erkenning van God as die erkenning van die oomblik, die oombliklike ontmoeting met God se oordeel en genade as oproep hier en nou tot die daad en oproep om met die goeie en slegte lotgevalle te skik (Bultmann [1948] 1968:136).

Bultmann (1984:188) merk op dat teoloë wat juis so gesteld is op die wetenskaplikheid van hulle werk, glad nie die unieke waarheid van die Christelike geloof in ag neem nie. Hulle laat hulle net deur die wetenskaplike waarheid lei en voel hulle nie gebonde aan die uitsprake van die geloof, wat die betrekking tussen geloof en sy voorwerp tot uitdrukking bring nie. Gevolglik kan so 'n 'teologie' nie van die voorwerp van die geloof en van God, praat nie. So word van die waarheid van die geloof afstand gedoen en wanneer van geloof gepraat word, word na geloof as 'n menslike houding verwys. Die voorwerp van ondersoek word die vroomheid, die godsdiens, die 'wêreld'. Hierdie 'teologie' wil van geloof praat sonder om in ag te neem waaraan die geloof glo, sonder om in ag te neem dat geloof net in betrekking tot sy voorwerp geloof genoem kan word.

\section{Waarheid en gewisheid}

Volgens Bultmann (1984:186) word daar ten onregte 'n onderskeid tussen waarheid en gewisheid van die Christelike geloof gemaak. Daar word aangeneem dat waarheid op algemeengeldigheid aanspraak moet kan maak, maar dit kan nie van die waarheid van die geloof gesê word dat dit algemeen geldig is nie. Tog word daar gewag gemaak van die gewisheid van die geloof. So 'n onderskeid maak egter van geloof 'n toestand, 'n houding van iemand, en dit het dan geen sin om van die waarheid, of selfs van die gewisheid daarvan te praat nie. Dat iemand seker van sy geloof is, kan dan net beteken dat hy oortuig is dat hy hom in 'n godsdienstige toestand bevind, soos wat hy weet dat hy opgewonde of hartseer is.
Om in die geloof seker te wees beteken sekerlik iets anders, naamlik om seker te wees van dit waaraan ek glo en te weet dat my geloof nie 'n illusie is nie. Geloof kan nie verstaan word as 'n toestand van die subjek nie, maar as sy betrekking tot sy voorwerp. Hy is seker van sy voorwerp en dat hy hom beleef soos hy werklik is. Gewisheid en waarheid van die geloof kan dan nie geskei word nie. Daar kan net sekerheid wees, as daar ook waarheid is. Soos wat ek 'n ander mens vertrou sonder dat dit by my duidelik registreer dat ek nou 'n vlak van vertroue betree het, so gebeur dit ook tussen my en God:

Der Glaube ist Tat und nur im Vollzuge seiner selbst sicher. Ihn sich nachträglich zum Problem machen, heisst seine Geschichtlichkeit verkennen, heisst, den Glauben statt in der Tat im Vohandenen suchen. Wer ihn aber im Vorhandenen sucht, wird mit dem Zweifel gestraft. (Bultmann [1927] 1972:113)

Wanneer iemand opgeroep sou word om te besluit, te kies, of net om iets te doen, word hy nie regtig daardeur gebind nie. Selfs al sou hy sy optrede daardeur laat lei, kan hy die gevoel van toevalligheid nie afskud nie. Sy beslissing gaan gebuk onder onbeslistheid. Die beslissing waarvoor die verkondiging van die evangelie ' $n$ mens stel, plaas hom egter glad nie in 'n neutrale of vrye posisie om vanuit dit 'n weloorwoë besluit te neem nie. Die ontmoeting waaroor die mens nie beskik nie, word reeds bepaal deur hoe hy luister. 'n Mens word ingevra en gekonfronteer met die antwoord dat hy sondaar is, dat hy uit eie krag lewe, en hier en nou die genade van God mag aangryp (Bultmann [1927] 1972:108110). Die genade van God is die toekoms wat die mens se verlede bevraagteken en hom vry maak om uit hierdie lewensveranderende toekoms te lewe, wat beteken om uit God te lewe (Bultmann [1940] 1968:71).

Die werklikheid van God, wat uit die verkondiging en geloof blyk, is nie ' $n$ feit wat vir 'n neutrale toeskouer toeganklik is nie. Die waarheid van vertroue of liefde wat aan my geskenk word, is ook nie vir 'n derde toeganklik nie. Vertroue en liefde word net sigbaar in die beantwoording daarvan in terug-vertroue en terug-liefde, en so blyk God se waarheid net in die gehoorsame geloof. Die mens verstaan God dus nie as 'n entiteit op sy eie nie, 'n bo-natuurlike wese met bepaalde eienskappe nie, maar soos dit in die Reformasie ook gesien is die mens verstaan God, deurdat Hy homself nuut verstaan (Bultmann 1984:201-202).

Die 'Etiese Teologie' wat sedert ongeveer 1850 in Nederland na vore gekom en ook in die daaropvolgende eeu in SuidAfrika in die Nederduitsch Hervormde Kerk van Afrika invloed uitgeoefen het, het op soortgelyke wyse probeer om aan die Christelike waarheid uiting te gee. Een van die prominente figure, J.H. Gunning Jr., verduidelik dat dit verwarrend is om die teologie 'eties', dit wil sê 'van sedelike aard' te wil noem. Dit is die waarheid wat sedelik, eties van karakter is:

En nu zeggen wij dat de waarheid ethisch is. Niet wij_eenige menschen of theologen, zijn ethisch, maar de waarheid zelve is het, om 't even of wij het erkennen of niet. Niet onze 'richting'is 
ethisch maar, nog eens, de waarheid, het bestaande zelf. Wij menschen kunnen het niet helpen. (Gunning 1878:372)

\section{Waarheid soek}

Bultmann (1984:13-14) kritiseer die beskouing dat ander wetenskappe die waarheid soek, terwyl die teologie die waarheid as gegewe in die kerklike leer kry en net die taak het om daaraan die gepaste uitdrukking te gee. So 'n benadering kan nie aanspraak maak op wetenskaplikheid nie; dit kom neer op estetiese of retoriese versorging van 'n gegewe. Egte teologie is nie die suiwere leer nie, maar is op soek na die leer wat aan die voorwerp van ondersoek getoets en weer herower moet word. Die 'suiwer leer' is nie iets wat eens en vir altyd vasgestel is nie; dit moet steeds deur die teologiese arbeid benader word om dit nog beter te verwoord.

Prediking is die wyse waarop in die kerk geleer word en die teologie soek die suiwere leer deur te bepaal wat verkondig moet word. Die prediker sê: Dit kan jy glo! En die hoorder vra: Wat moet, wat mag ek glo? Die suiwere leer is dit wat ek mag glo, fides quae creditur (geloof, wat mens glo) = quod deus dixit, (wat God sê). Die teologiese ensiklopedie verduidelik wat dit inhou en hoe hierdie inhoud die teologiebeoefening bepaal.

Teologie is nie direkte verkondiging nie en wil dit ook nie wees nie. As wetenskaplike arbeid kom dit net tot uitsprake van relatiewe geldigheid, terwyl die woordverkondiging net sin het as dit die aanspraak vir die konkrete omstandighede oordra. In die teologie word daar steeds gepoog om die regte begrippe te vind, ' $n$ eis wat nie aan die verkondiging gestel kan word nie, want as verkondiging bring dit die aanspraak en dit is genoeg. Die verkondiging is nie bloot oriënterende mededeling nie, maar die beslissende woord waarin die Goddelike ontferming geskied (Bultmann [1925] 1963:69).

Die geskiedenisnavorsing hou 'n bedreiging in vir die geloof net wanneer iemand die geloof op 'n historiese basis wil legitimeer. En mense probeer dit doen ten spyte daarvan dat die verkondiging glad nie histories bevestig of verwerp kan word nie. Omdat die evangelie en die verkondiging daarvan $\mathrm{u}$ Goddelike daad is, is dit onthef van historiese waarneming (Bultmann [1931] 1968:16).

Idealisme beantwoord die vraag na teologie nie vanuit sy voorwerp nie, maar orden dit in die sisteem van die rede en so word dit 'n funksie van die menslike gees (Bultmann 1984:29). Omdat hy só sy voorwerp prysgee, soek hy na iets anders en vind dit in die fides qua creditur (geloof, waarmee mens glo) wat as godsdiens verstaan word. Maar sonder sy voorwerp verloor die geloof sy karakter as geloof en word dit 'n menslike houding of vermoë. Geloof kan egter volgens Bultmann ([1924] 1972:22-23) nie as 'n houding of toestand van die mens waargeneem word nie. Dit is nie 'n besondere deel van 'n mens se geesteslewe nie. In soverre dit 'n bewussynstoestand is, is dit nie geloof nie. In geloof word die bevraagtekening van die hele mens deur God erken en word hy geregverdig as nuwe mens - juis dit word geglo op grond van God se beloftes en nie uit eie ervarings nie. Daarom kan alle belewenisgodsdiens, vroomheid, sondegevoel en begeestering bevraagteken word.

\section{Glo en verstaan}

Glo en verstaan is dieselfde wanneer onder verstaan bedoel word dit wat Bultmann as selfverstaan beskryf: 'Glauben ist ein neues Verständnis der persönlichen Existenz. Anders ausgedrückt: Gottes Handeln verleiht uns ein neues Verständnis unserer selbst' (Bultmann [1958] 1968:181). Dit wil sê wanneer iemand homself uit die geloof verstaan, dan sou geloof en verstaan so dieselfde wees soos wat in die Johannesevangelie om te glo en om te ken dieselfde is (Bultmann 1968a:333).

Wanneer 'n mens egter as ' $n$ ander moontlikheid verstaan begryp as die poging om oor die geloof na te dink en dit dan in woorde en begrippe uit te druk, dit wil sê die geloof teologies te formuleer, dan is geloof en verstaan nie dieselfde nie, dan is die verhouding dié van gelowige eksistensie en teologie wat wetenskaplike doenigheid in die wydste sin van die woord is.

Op die vraag of teologie geloof veronderstel, ontvou Bultmann (1984:15-16) sy antwoord in ' $n$ ja en 'n nee. Dis ja omdat dit sinloos sou wees om sonder geloof teologie te beoefen. Dis nee omdat die geloof nie as 'n gegewe beskou kan word nie. Bultmann (1984:17-18) meen dat in die teologie 'n skuif gemaak word van wetenskap van 'wát mens glo', fides quae creditur na wetenskap van 'dát mens glo', fides qua creditur. Die inhoud van die geloof en die vraag na waarheid val in so 'n verskuiwing weg. Om byvoorbeeld vas te stel dat die Christelike geloof die mees gesofistikeerde van alle gelowe is, sê eintlik niks nie, want 'n mens wil weet of dit die regte geloof is (Bultmann 1984:20). In 'n brief aan sy vriend, Friedrich Gogarten, skryf Bultmann (Gökeritz 2002:164) dat die vorige geslag, die geslag van die toeskouer-geloof, gevra het wat die wese van godsdiens sou wees, terwyl ons, die huidige geslag, eerder vra of dit waaraan die geloof glo, waar is, want geloof kan net geloof wees deur dit waaraan geglo word.

\section{Ortodoksie}

Bultmann verskil van die Ortodoksie deurdat hy volhou dat daar een evangelie, kerugma, dogma is wat in die kanon deur verskeie teologiese ontwerpe uitgelê word. Die een evangelie word in verskillende omstandighede deur verskillende teoloë uitgewerk om dit nuut te laat klink. Paulus en Johannes gebruik elkeen sy eie kenmerkende begrippe om die evangelie aan hulle gemeentes oor te dra. En Bultmann kon weer in sy uitleg daarin slaag om sowel Paulus as Johannes se teologie in sy eie kenmerkende denkwyse te vertaal.

In die Ortodoksie word die verskil tussen evangelie en teologie nie verstaan nie. Wat dan gebeur is dat die teologie, wat uitleg van die evangelie is, in die plek gestel word van die evangelie. Die Ortodoksie maak van die fides quae creditur, van dit wat God sê, die evangelie, 'n teologie, iets wat die 
mens sê. So is byvoorbeeld die maagdelike geboortetradisie afhanklik van die evangelie, maar die evangelie is nie afhanklik van daardie tradisie nie. Die Ortodoksie stel die teologiese uitwerking van die evangelie in die plek van die evangelie. ' $n$ Mensewoord kom in die plek van die Godswoord. Die inhoud van die geloof word op dié manier iets wat as algemene waarhede erken en aanvaar word in plaas van iets wat verkondig en bely word; die inhoud van die geloof word iets wat die mens sê en nie iets wat tot hom spreek nie (Bultmann 1984:31).

Terwyl Melanchthon hom kon beperk tot notitia en fiducia, dit wil sê die wete van die inhoud van die leer en die vertroue op hierdie inhoud, is die assensus later bygevoeg omdat die fides quae creditur nie meer die voorwerp van geloof is nie, maar 'n wetenskaplike leer en daarom moes die aanvaarding tussen die notitia en fiducia inkom (Bultmann 1984:33).

\section{Onkenbaarheid van God}

Bultmann (1984:51) wys daarop dat God vir die wetenskap onkenbaar is. Hy bedoel daarmee dat daar nie algemene waarhede oor God kwytgeraak kan word waarby die stellinginname van die spreker of van God onafhanklik van mekaar sou bly nie. As die vraag na waarheid ook die vraag na God is, word dit 'n eksistensiële vraag, wat net hier en nou deur iemand beantwoord kan word, want die vraag word vanuit die Goddelike inisiatief deur die aanspraak van die oomblik gestel.

Vrae waarom God dit of dat gedoen het, dit of dat toegelaat het, berus op ' $n$ misverstand en vra nie werklik na God nie, maar na 'n verstaanbare wêreldbeginsel van waaruit die wêreld verstaan kan word. Maar so 'n beginsel sal self wêrelds wees en as ons so 'n beginsel nog nie kan vind nie, beteken dit net dat ons wêreldkennis nog tekort skiet.

Die besef dat ons die wêreld as geheel nie verstaan nie en dat die wêreld nie ons woning is nie, en dat ons hier angstig en benoud raak, is ook nog nie God nie. Die irrasionele is maar net die teendeel van die rasionele en nie gelyk aan God nie. In die irrasionalisme word die verstand gevange geneem deur gehoorsaamheid van die geloof aan 'n uiterlike outoriteit, byvoorbeeld om te buig voor bepaalde Bybeluitsprake. Dit is ook sinloos om God die onbegryplike wese te noem, want dit maak van Hom 'n gegewe iets, bloot die teendeel van dit wat begryp kan word (Bultmann 1984:53-54). Ons kan God nie objek van ons optrede maak nie, ook nie die objek van ons denke nie. Hy is nie tot ons beskikking as objek nie. Van God, wat Hom aan elke greep van die mens onttrek, kan ons net praat omdat Hy Hom openbaar en die openbaring kan net in geloof verneem word (Bultmann 1984:63).

\section{Openbaring}

Die inhoud van die openbaring is God self, die aanspraak wat Hy nou maak; Hy bly die subjek. Ek word vooraf deur Hom verstaan en my verstaan kan niks anders wees as die antwoord op die vooraf verstaan van myself nie (Bultmann
1984:82). Dit wat in Christus gebeur, is die daad van die liefde van God wat my sonde vergewe; wat die nuwe bedeling vir my laat aanbreek. Die openbaring hoef eintlik nie nog te sê wat God se genade behels nie; 'n mens het 'n aanvoeling daarvoor. Dit sê eerder: Jóú sonde is jóú vergewe. En deur dit aan te kondig, word duidelik gemaak dat die eerste en laaste sonde van die mens is om uit eie krag homself te verwesenlik (Bultmann 1968b:272; 1984:94). Hierdie insig word nie deur 'n eenmalige ontdekking verseker nie. Wanneer ons by die doel kom, bly ons steeds op pad. En om op pad te wees, is om by die doel te wees. In hierdie sin is Christus die weg, die waarheid en die lewe (Joh. 14:6). Hy wys nie net die weg; leer nie net die waarheid; bemiddel nie net die lewe nie, maar is dit alles (Bultmann 1984:74).

\section{Geloof}

Bultmann (1984:97-98) beskryf die Katolieke opvatting van geloof as die vir-die-waarheid-hou van die openbaringswaarhede. As openbaringswaarhede geld:

1. die bestaan van God

2. die hiernamaalse vergelding

3. triniteit

4. inkarnasie

5. onsterflikheid van die siel

6. noodwendigheid van genade.

'n Mens wat by punte 5 en 6 nog wonder kan oorgesien word. Dit word as genoegsaam beskou wanneer 'n mens ' $n$ minder ontwikkelde geloof sou hê, solank hy net seker is dat dit wat die Kerk leer, waar is. Die benadering kan as dogmatiese of teoretiese geloof aan die geopenbaarde waarhede beskryf word.

In die Protestantse Dogmatiek word drie bestanddele van die geloof onderskei: notitia, assensus, fiducia (Bultmann 1984:102-103). Dat notitia kennisname genoem word, kan verkeerdelik die indruk van vir-die-waarheid-hou van openbaringswaarhede wek, maar dit word eerder bedoel in die sin dat die geloof in ' $n$ bepaalde verkondiging vir die mens in bepaalde omstandighede gebring word. Daar is nie ' $n$ wete op sigself van waarhede nie, die notitia manifesteer as 'n manier van lewe. Die mens kry insae in die oordeel van God en vir wie só onder die kruis gebuig het, is die boodskap van die opstanding geloofwaardig en verstaanbaar.

Oorspronklik is die assensus nie van die fiducia onderskei nie en dui dit op die oorgawe van die mens aan die duidelikgeworde genade van God. Later is daar onderskei tussen die assensus generalis wat die algemene belofte van God en die verdienste van Christus as waar beoordeel en die assensus specialis wat die sondaar bekeer en herbore laat word. Maar dit is 'n dwaling, want sonder die pertinente toepassing op 'n mens kan die beloftes nie as waar aanvaar word nie. As 'n verdere ontwikkeling hieruit het die Ortodoksie gekom wat volhou dat die heilsfeite eers erken moet word voordat hulle die grondslag van die geloof kan vorm; terwyl dit tog eers in die geloof as heilsfeite kenbaar word. So word die teologie, 
die suiwer leer, dan die voorwerp van die geloof en verplaas dit die deur notitia bemiddelde heilsdaad.

Die Christelike geloof is nie die onkritiese aanvaarding van historiese mededelings, fides historica, nie. Tog is geloof die sekerheid dat deur die historiese optrede van Jesus Christus die geskiedenis as heilsaam gekwalifiseer is deurdat deur Hom die verkondigde vergewing van sonde verkondig word, en die mens so in sy hede bepaal word om as geliefde-liefhebbende sy hier en nou te verstaan en te doen wat die hand vind om te doen (Bultmann 1984:130-131). Die notitia wat nie deur die historiese ondersoek nie, maar deur die verkondiging bemiddel word, hoort by die geloof. Jesus Christus se koms na die wêreld toe maak, deur die verkondiging, 'n geskiedenis van sonde tot 'n geskiedenis van genade. Geloof is daarom nie die aantekening van algemene waarhede nie, maar die gehoorsame aanneming van die boodskap van die vergewing van sonde en die nuwe lewe in Christus. In hierdie gehoorsaamheid erken ek dat ek sondaar is, 'n samehang waaruit net 'n daad van God my red (Bultmann 1984:130-131). In die genade word die oordeel erken, omdat ek in die genade leer wat sonde is en in die oordeel erken ek die genade omdat ek as geoordeelde weet van genade (Bultmann 1984:132). Die blye boodskap is die boodskap van oordeel oor die sonde.

Gehoorsaamheid sluit vertroue in, maar is nie bedoel as 'n algemene Godsvertroue nie, eerder 'n vertroue in die vergewing (Bultmann 1984:132). Christelike Godsvertroue is nie ' $n$ algemene staatmaak op die doelmatigheid van die verloop van die wêreld, waarby my belange gedien word nie, of 'n algemene oortuiging dat God op die troon sit en alles mooi stuur, waarby 'mooi' deur my ideale bepaal word nie. Dat God in beheer is, soos daar dikwels gesê word, beteken ook dat Hy my sonde vergewe.

Ons naaste is sondaars soos ons en begenadigdes soos ons. Ons benader hulle nie vanuit ' $n$ optimistiese oortuiging oor die goedheid van die mensdom nie, maar vanuit die ontvangde vergewing. So nie, bly ons 'liefde' in ons eie besluit gegrond, bly dit prestasie en is dit nie liefde nie (Bultmann 1984:136).

\section{Wat is teologie?}

Die Christelike geloof het 'n bepaalde verstaan van openbaring en die gelowige bestaan. Dit word in die teologie ontvou. Die kritiese uitbouing van hierdie selfverstaan kan terugslaan as selfkritiek teen die gelowige. Hy staan altyd in gevaar om die Skepper met die skepping te vervang; om die openbaring met belewenisse of algemene waarhede te verwar; om die geloof met 'n houding, sê maar van die Ortodoksie of van 'n optimisme, te vervang; om die liefde met simpatie gevoelens te verwar; die kerk met 'n vereniging te verwar. Die verhouding tot die voorwerp van die teologie word nie opgestel nie, maar veronderstel. Die teologie herinner daaraan en bou dit uit (Bultmann 1984:161).
God se openbaring as voorwerp van die teologie is egter nie tot beskikking van die teologie soos ander wetenskappe hulle voorwerpe kan hanteer nie. Teologie kan net as geloofsdaad beoefen word. Dat dit wel gebeur, kan nie gewaarborg word nie. Dit hou in dat dit net gedoen kan word waar dit gedoen moet word. Mens kan dit nie uit belangstelling of nuuskierigheid doen nie. Teologie is noodsaaklik binne die kerk as die gemeenskap van gelowiges. Teologie bly ook daarvan bewus dat die waarheid van sy uitsprake nie in sy mag lê nie, maar deur God voltrek moet word (Bultmann 1984:166). Die teoloog en prediker is sondaar en kan nie uit God praat nie, net oor God. Maar die Here wil die sondaars regverdig en sorg dat ons sy aanspraak hoor (Bultmann [1925] 1963:68).

As studiemateriaal benut die teologie die Skrif, die dogma, die historiese ontwikkeling van die teologie. In soverre in hierdie stukke die verkondiging optree, vorm dit die gesag vir die teologie (Bultmann 1984:168). Die empiriese kerk beskik nie oor die gesag nie; die teologie self ontdek die gesag. Aangesien die verkondiging van die Skrif die openbaring is en alle ander verkondiging daarna terugverwys, vorm die Skrif die outoriteit, die enigste outoriteit vir die teologie. Die eerste en vernaamste taak van die teologie is dus om die Skrif te verstaan. Teologie is aan die een kant die beskrywing van die menslike bestaan soos deur God bepaal en aan die ander kant verklaring van die Skrif. Bultmann (1984:169-170) sien nie dat sistematiese teologie as vak binne die raamwerk van die historiese of Nuwe-Testamentiese gekonstitueer word nie. Die dogmatiese benadering konkurreer met die historiese metode.

Bultmann ([1933] 1968:295-298) merk op dat daar soveel klem op die voorbereiding van teologiestudente vir die praktyk gelê word dat hy daarteen moet waarsku dat die swaartepunt van die opleiding in die proses verskuif na die afrigting vir die praktyk. Hy wys daarop dat die praktykteorie nie teologie is nie en dat die praktyk ook verskil van wat vooraf ingeoefen sou word. Gewoonlik word daarna verwys dat die wetenskap van die praktiese lewe vervreemd geraak het. Bultmann draai die rolle om en waarsku dat die praktiese lewe wat die betrekking tot die wetenskap verloor, blind en oneg word. Teologie as wetenskap kan kritiek lewer op 'n lewe wat 'n besigheid geword het.

\section{Erkenning Mededingende belange}

Die outeur verklaar dat hy geen finansiële of persoonlike verhouding(s) het wat hom op 'n voordelige of nadelige wyse in die skryf van die artikel beïnvloed het nie.

\section{Literatuurverwysings}

Bultmann, R. [1924] 1972, 'Die liberale Theologie und die jüngste theologische Bewegung', in Glauben und Verstehen, Gesammelte Aufsätze, vol. I, pp. 1-25, Mohr, Tübingen.

Bultmann, R., [1925] 1963, 'Das Problem einer theologische Exegese des Neuen Testaments', in J. Moltmann (Hrsg.), Anfänge der dialektischen Theologie, Teil II, pp. 47-71, Kaiser, München. (Theologische Bücherei: Neudrucke und Berichte aus dem 20, Jahrhundert, Band 17, Systematische Theologie). 
Bultmann, R., [1927] 1972, 'Zur Frage der Christologie', in Glauben und Verstehen, Gesammelte Aufsätze, vol. I, pp. 85-113, Mohr, Tübingen.

Bultmann, R., [1931] 1968, 'Die Krisis des Glaubens', in Glauben und Verstehen: Gesammelte Aufsätze, vol. II, pp. 1-19, Mohr, Tübingen.

Bultmann, R. [1933] 1968, 'Zur Frage der Reform des theologischen Studiums', in Glauben und Verstehen: Gesammelte Aufsätze, vol. II, pp. 294-298, Mohr, Tübingen.

Bultmann, R., [1940] 1968, 'Das Verständnis von Welt und Mensch im Neuen Testament und im Griechentum', in Glauben und Verstehen: Gesammelte Aufsätze, vol. II, pp. 59-78, Mohr, Tübingen.

Bultmann, R., [1948] 1968, 'Humanismus und Christentum', in Glauben und Verstehen, Gesammelte Aufsätze, vol II, pp. 133-148, Mohr, Tübingen.

Bultmann, R., [1958] 1968, 'Jesus Christus und die Mythologie (Deutsche Übersetzung von "Jesus Christ and Mythology"', New York 1958 = 'Jesus Christus und die Mythology', Stundenbuch 47, Furche-Verlag, Hamburg 1964, pp. 7-101', in Glauben und Verstehen: Gesammelte Aufsätze, vol. IV, pp. 141-189, Mohr, Tübingen.
Bultmann, R., 1968a, Das Evangelium des Johannes, 10 Auflage, Vandenhoeck, Göttingen.

Bultmann, R., 1968b, 'Formen menschlicher Gemeinschaft', in Glauben und Verstehen, Gesammelte Aufsätze, vol. II, pp. 262-273, Mohr, Tübingen.

Bultmann, R., 1984, Theologische Enzyklopädie, Hrsg. von E. Jüngel \& K.W. Müller Mohr, Tübingen.

Ebeling, G., 1978, 'Der Lebensbezug der Theologie', in N. Janowski \& E. Stammler (Hrsg.), Was ist los mit der deutschen Theologie? Antworten auf eine Anfrage, pp. 9-24, Kreuz, Stuttgart.

Gökeritz, H.G. (Hrsg.), 2002, Rudolf Bultmann - Friedrich Gogarten Briefwechsel 1921-1967, Mohr, Tübingen.

Gunning, J.H. Jr. 1878, 'Het ethisch karakter der waarheid: Brief aan den hoogleeraar dr. J.J. van Oosterzee', Stemmen voor Waarheid en Vrede. Evangelisch Tijdschrift voor de Protestantsche Kerken 15, 366-399. 